\title{
Lítil nýrnafrumukrabbamein og fjarmeinvörp
}

Pétur Sólmar Guðjónsson ${ }^{1}$ læknanemi, Elín Maríusdóttir ${ }^{2}$ læknir, Helga Björk Pálsdóttir ${ }^{2}$ læknir, Guðmundur Vikar Einarsson² læknir, Eiríkur Jónsson² læknir, Vigdís Pétursdóttir ${ }^{3}$ meinafræðingur, Sverrir Harðarson ${ }^{3}$ meinafræðingur, Martin Ingi Sigurðsson ${ }^{2}$ læknir, Tómas Guðbjartsson ${ }^{1,2}$ læknir

\section{ÁGRIP}

Inngangur: Horfur lítilla nýrnafrumukrabbameina eru almennt taldar góðar og mælt er með hlutabrottnámi ef æxli eru undir $4 \mathrm{~cm}$. Markmið pessarar rannsóknar var að rannsaka tíoni fjarmeinvarpa frá litlum nýrnafrumukrabbameinum en pau hafa ekki verið rannsökuð áđur hér á landi. Efniviður og aðferðir: Af 1102 sjúklingum sem greindust með nýrnafrumukrabbamein á tímabilinu 1971-2010 var litið sérstaklega á 257 æxli $\leq 4$ cm og sjúklingar með meinvörp við greiningu bornir saman við sjúklinga án meinvarpa. Upplýsingar fengust úr sjúkraskrám og vefjagerð, TNM-stig og sjúkdómasértæk lifun var borin saman í hópunum. Niðurstöður: Hlutfall lítilla nýrnafrumukrabbamein hækkaði úr 9\% fyrsta áratuginn í 33\% pann síðasta ( $p<0,001)$ á sama tíma og hlutfall tilviljanagreiningar jókst úr 14\% i 39\%. Alls greindust 25 af 257 sjúklingum (10\%) með lítil nýrnafrumukrabbamein með fjarmeinvörp, oftast í lungum og beinum. Sjúklingar með meinvörp voru 1,9 árum eldri, æxlin 0,2 cm stærri og oftar staðsett í hægra nýra. Vefjagerð var sambærileg í báðum hópum en æxli greindust síður fyrir tilviljun hjá sjúklingum með meinvörp, blóðrauði peirra var lægri og bæði Fuhrman-gráđa og T-stig hærra. Fimm ára lifun sjúklinga með meinvörp var $7 \%$ borið saman við $94 \%$ hjá viðmiðunarhópi $(p<0,001)$.

Ályktun: Við greiningu eru 10\% sjúklinga með lítil nýrnafrumukrabbamein með fjarmeinvörp. Petta er óvenju hátt hlutfall en í flestum öðrum rannsóknum hefur aðeins verið litið á sjúklinga sem gengist hafa undir skurðaðgerð. Sjúklingar með meinvörp eru marktækt eldri, greinast oftar með einkenni sjúkdómsins, hafa stærri frumæxli og verri lifun. Lítil nýrnafrumukrabbamein geta pví verið útbreiddur sjúkdómur við greiningu og verður að taka alvarlega.
${ }^{1}$ Læknadeild Háskóla Íslands, ${ }^{2}$ skurðsviði Landspítala, 3rannsóknarstofa í meinafræði, Landspítala.

Fyrirspurnir: Tómas Guðbjartsso tomasgud@landspitali.is

Greinin barst: 16. mars 2012 sampykkt til birtingar 22. október 2012

\section{Inngangur}

Nýrnafrumukrabbamein (NFK) er í kringum 3\% nýgreindra krabbameina og er nýgengi pess hér á landi með pví hæsta sem pekkist. ${ }^{1}$ Síðustu áratugi hefur greining lítilla $(\leq 4 \mathrm{~cm})$ NFK orðið algengari vegna framfara sem orðið hafa í myndgreiningu og aðgengi að rannsóknum hefur aukist. ${ }^{2}$ Lítil hætta hefur verið talin á pví að lítil NFK meinverpist og horfur pessara sjúklinga hafa almennt verið taldar góðar. Í nýlegum alpjóðlegum leiðbeiningum frá Evrópu og Bandaríkjunum er mælt með hlutabrottnámi í stað fulls brottnáms pegar um lítil NFK er að ræða. ${ }^{3,4}$ Er ástæðan fyrst og fremst sú að hlutabrottnám varðveitir betur nýrnastarfsemi sem getur bætt langtímahorfur pessara sjúklinga.,6 Góðar horfur lítilla NFK eru einnig notaðar sem röksemd fyrir virku eftirliti (active surveilance) í stað skurðaðgerðar, til dæmis hjá eldri einstaklingum eða fjölveikum par sem skurðaðgerð er talin of áhættusöm. ${ }^{78}$

Tíðni meinvarpa eykst með aukinni stærð NFK, og á pað sérstaklega við um æxli sem eru yfir $7 \mathrm{~cm}$ að stærð. ${ }^{9}$ Fyrir minni æxli er sambandið flóknara, sérstaklega fyrir æxli sem eru undir fjórum cm. Pannig eru til rannsóknir sem hafa sýnt línulegt samband milli stærðar æxlis og tíðni meinvarpa ${ }^{10,11}$ en aðrar rannsóknir hafa ekki getað sýnt fram á slíkt samband. ${ }^{22}$ Í nýlegri sænskri rannsókn, National Swedish Kidney Cancer Quality Register (NSKCR), sem náði til 2033 sjúklinga, var tíðni meinvarpa hjá sjúklingum með æxli undir $4 \mathrm{~cm} 7 \%$ og $32 \%$ fyrir æxli 6-7 cm að stærð. ${ }^{10}$ Í flestum erlendu rannsóknanna, að peirri sænsku undanskilinni, var aðeins litið á sjúklinga sem gengust undir nýrnaskurðaðgerð. ${ }^{11-13}$
Raunveruleg tíðni meinvarpa fyrir lítil NFK gæti pví hafa verið vanmetin í eldri rannsóknum. Tilgangur pessarar lýðgrunduðu rannsóknar var að meta hversu margir sjúklingar með lítil NFK hafa fjarmeinvörp við greiningu og hvaða pættir greina pá sjúklinga frá peim sem eru án meinvarpa.

\section{Efniviður og aðferðir}

Rannsóknin var afturskyggn og náði til allra sjúklinga á Íslandi sem greindust með NFK frá 1. janúar 1971 til 31. desember 2010. Stuðst var við gagnagrunn á pvagfæraskurðdeild Landspítala en par eru skráð öll NFK-tilfelli sem greinst hafa á Íslandi frá 1971, samtals 1102 tilfelli. Gagnagrunnurinn byggist á gögnum frá Krabbameinsskrá Krabbameinsfélags Íslands, Rannsóknarstofu í meinafræði á Landspítala og meinafræðideild Sjúkrahúss Akureyrar, ásamt greiningar- og aðgerðarskrám Landspítala og Sjúkrahúss Akureyrar.

Klínískar upplýsingar um sjúklinga fengust úr sjúkraskrám og voru skráðar eftirfarandi breytur: kyn, greiningarmánuður og ár, aldur við greiningu, reykingasaga og hvort krabbameinið var greint vegna einkenna eða fyrir tilviljun. Einnig voru skráð einkenni, tímalengd einkenna, myndrannsóknir og blóðrauði fyrir aðgerð, tegund aðgerðar, hvort og pá hvar meinvörp voru til staðar.

Í rannsóknarhópnum voru 257 sjúklingar með NFK $\leq 4 \mathrm{~cm}$ og var stærð æxlanna fengin úr vefjasvörum eða myndrannsóknum ef vefjasýni voru ekki til. Af pessum 


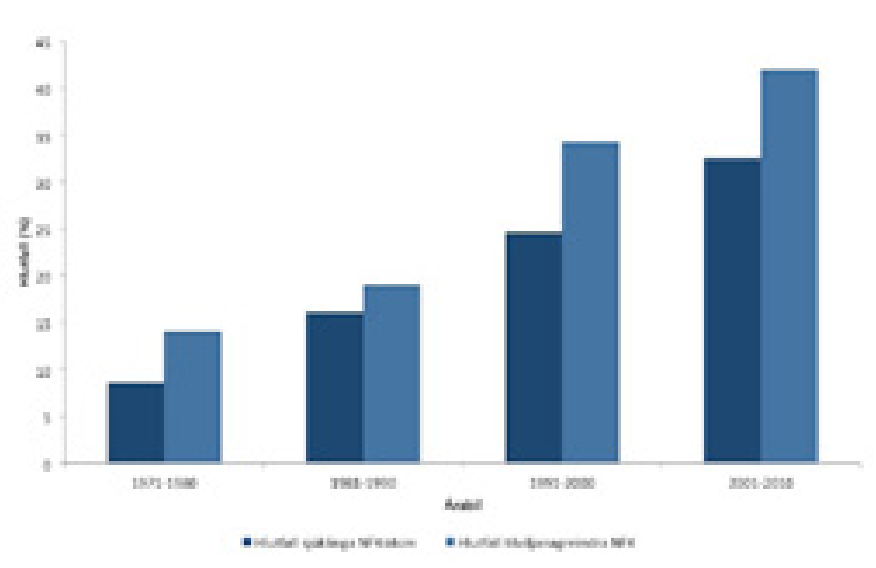

Mynd 1. Hlutfall sjúklinga (bæði kyn saman) með lítil nýrnafrumukrabbamein ( $\leq 4$ cm) ásamt hlutfalli tilviljanagreindra æxla af öllum greindum tilfellum á Íslandi, skipt eftir 10 ára tímabilum frá 1971-2010. NFK=nýrnafrumukrabbamein.

257 sjúklingum voru peir 25 sem höfðu meinvörp við greiningu og voru peir bornir saman við 232 sjúklinga án meinvarpa hvað varðar aldur, vefjagerð, gráðun og T-stig.

Stigun sjúkdómsins var ákveðin út frá stærð æxlis og útbreiðslu, og var stuðst við 6. útgáfu TNM-stigunarkerfisins. Vefjagerð og gráða æxlanna var yfirfarin af tveimur meinafræðingum út frá flokkunarkerfi Alpjóðaheilbrigðismálastofnunarinnar frá 2004. ${ }^{14}$

Upplýsingar voru skráðar í Excel en við tölfræðilega úrvinnslu var notast við tölfræðiforritið R. Við samanburð normaldreifðra stærða var notast við t-próf en Fisher's exact próf eða kí-kvaðrat próf við flokkabreytur. Marktækni miðaðist við p-gildi <0,05. Upplýsingar um dánarmein fengust frá Hagstofu. Sjúkdómasértæk lifun var reiknuð út með aðferð Kaplan-Meier og lifun hópa borin saman með log-rank prófi. Eftirlitstími sjúklinga miðaðist við tímann frá greiningardegi krabbameins að dánardegi eða 1. júlí 2011.

Leyfi fyrir rannsókninni fengust frá Vísindasiðanefnd, Persónuvernd og frá framkvæmdarstjóra lækninga á Landspítala.

\section{Niðurstöður}

Af 1102 sjúklingum sem greindust með NFK á rannsóknartímabilinu reyndust 257 (23\%) vera með æxli undir $4 \mathrm{~cm}$ að stærð. Hlutfall lítilla NFK jókst úr $9 \%$ á fyrsta áratug rannsóknartímabilsins 1́33\% á peim síðasta $(\mathrm{p}<0,001)$ og hlutfall tilviljanagreininga jókst á sömu tímabilum úr 14\% 1́ 39\% (p<0,001) (mynd 1). Af 257 sjúklingum með NFK undir $4 \mathrm{~cm}$ að stærð, voru 146 (57\%) greindir fyrir tilviljun, 77 karlar (53\%) og 69 konur (47\%). Alls reyndust 25 sjúklingar (10\%) með fjarmeinvörp við greiningu, oftast í lungum (48\%) og beinum (40\%). Tíðni meinvarpa í öðrum líffærum eru sýnd í töflu I.

Pegar litið var á tíðni meinvarpa á fjórum stærðarbilum, frá 0 og upp í $4 \mathrm{~cm}$, reyndist enginn af 8 sjúklingum með æxli undir 1 cm hafa meinvörp (0\%), prír af 33 (9\%) með 1,1-2 cm stór æxli, 11 af 104 sjúklingum (11\%) með æxli á bilinu 2,1-3 cm og 11 af 112 (10\%) með æxli á bilinu 3,1-4 cm. Munurinn á tíðni meinvarpa á milli pessara fjögurra stærðarbila reyndist ekki marktækur nema fyrir minnstu æxlin $(p=0,1)$.
Tafla I. Staðsetning meinvarpa hjá 25 sjúklingum með lítil $(\leq 4 \mathrm{~cm})$ nýrnafrumukrabbamein á Íslandi 1971-2010. Sjúklingar geta haft meinvörp í fleiri en einu liffæri.

\begin{tabular}{lc}
\hline Staðsetning & \\
\hline Lungu & $12(48)$ \\
\hline Bein & $10(40)$ \\
\hline Lifur & $8(32)$ \\
\hline Heili & $2(8)$ \\
\hline Eitlar & $8(32)$ \\
\hline Önnur líffæri & $11(44)$ \\
\hline
\end{tabular}

Tafla II. Samanburður á einkennum sjúklinga með meinvörp við greiningu $(n=21)$ og peim sem ekki höfðu meinvörp $(n=90)$. Sjúklingar sem greindir voru fyrir tilviljun í hópunum tveimur (fjórum í meinvarpahópi og 142 án meinvarpa) var sleppt. Sjúklingar geta haft fleiri en eitt einkenni.

\begin{tabular}{lcc}
\hline Einkenni & $\begin{array}{c}\text { Meinvörp } \\
\mathrm{n}=21\end{array}$ & $\begin{array}{c}\text { Án meinvarpa } \\
\mathrm{n}=90\end{array}$ \\
\hline Kviðverkur & $8(38)$ & $52(58)$ \\
\hline Megrun & $6(29)$ & $16(18)$ \\
\hline Bersæ blóðmiga & $2(10)$ & $33(37)$ \\
\hline Einkenni blóðleysis & $2(10)$ & $7(8)$ \\
\hline Háprýstingur & $1(5)$ & $2(2)$ \\
\hline Hiti & $0(0)$ & $6(7)$ \\
\hline Rauðkornafjölgun & $0(0)$ & $1(1)$ \\
\hline Einkenni fjarmeinvarpa & $13(62)$ & $18(20)$ \\
\hline Önnur einkenni & $7(33)$ &
\end{tabular}

Fjórir sjúklingar með meinvörp (16\%) voru greindir fyrir tilviljun en 21 vegna einkenna, oftast kviðverkja (38\%) og megrunar (29\%). Í viðmiðunarhópi voru marktækt fleiri, eða 61\% greindir fyrir tilviljun $(\mathrm{p}<0,001)$ og algengasta einkennið kviðverkir $(23 \%)$ og bersæ blóðmiga (14\%). Önnur einkenni eru sýnd í töflu II.

Í töflu III sést samanburður hópa. Kynjahlutfall og hlutfall æxla í hægra nýra reyndist sambærilegt í báđum hópum. Hins vegar voru sjúklingar með meinvörp 1,9 árum eldri $(\mathrm{p}=0,009)$, æxlin $0,24 \mathrm{~cm}$ stærri $(\mathrm{p}=0,03)$ og á hærra T-stigi $(\mathrm{p}<0,001)$, auk pess sem blóðrauði peirra var lægri $(p=0,04)$. Vefjagerð var hins vegar ekki marktækt frábrugðin $(p=0,07)$ og tærfrumugerð langalgengust í báðum hópum.

Alls gengust 232 sjúklingar (90\%) í báðum hópum undir skurðaðgerð par sem æxlið var fjarlægt, í 10 tilvikum með kviðsjá. Í 25 aðgerðanna (11\%) var gert hlutabrottnám, í öllum tilvikum gerð á sjúklingum án meinvarpa með lækningu að markmiði. Í hópi sjúklinga með meinvörp gengust 9 (36\%) undir líknandi skurðaðgerð og var um fullt brottnám að ræða í öllum tilvikum.

Fimm ára sjúkdómasértæk lifun sjúklinga var marktækt betri fyrir sjúklinga með lítil NFK borið saman við sjúklinga með nýrnakrabbamein af öllum stærðum (56\% á móti 86\%, p<0,001). Einnig var 5 ára lifun sjúklinga með lítil NFK og meinvörp marktækt verri en lifun sjúklinga með lítil NFK án meinvarpa (7\% á móti 94\%, p<0,001) (mynd 2). Eins árs lifun sjúklinga með meinvörp sem gengust undir líknandi nýrnabrottnám var betri en lifun peirra sem fengu aðra líknandi meðferð (67\% á móti 13\%, p=0,01). 
Tafla III. Samanburður á sjúklingum með lítil nýrnafrumukrabbamein $(\leq 4 \mathrm{~cm})$, eftir pví hvort peir höfðu meinvörp við greiningu eða voru án meinvarpa.

\begin{tabular}{|c|c|c|c|}
\hline & $\begin{array}{c}\text { Meinvörp } \\
n=25\end{array}$ & $\begin{array}{c}\text { Án meinvarpa } \\
n=232\end{array}$ & p-gildi \\
\hline $\begin{array}{l}\text { Aldur } \\
\text { (bil) }\end{array}$ & $\begin{array}{l}66 \pm 13 \\
(33-82)\end{array}$ & $\begin{array}{l}64 \pm 12 \\
(23-96)\end{array}$ & 0,009 \\
\hline Kynjahlutfall (karlar/konur) & 1,1 & 1,3 & 0,76 \\
\hline $\begin{array}{l}\text { Stærð, cm } \\
\text { (bil) }\end{array}$ & $\begin{array}{l}3,1 \pm 0,7 \\
(1,8-4,0)\end{array}$ & $\begin{array}{c}2,9 \pm 0,8 \\
(0,3-4,0)\end{array}$ & 0,03 \\
\hline \multicolumn{4}{|l|}{ Staðsetning } \\
\hline Hægri & $12(48)$ & $140(60)$ & \multirow{2}{*}{0,29} \\
\hline Vinstri & $13(52)$ & $92(40)$ & \\
\hline $\begin{array}{l}\text { Blóðrauði, g/L } \\
\text { (bil) }\end{array}$ & $\begin{array}{l}122 \pm 19 \\
(75-155)\end{array}$ & $\begin{array}{l}138 \pm 18 \\
(80-220)\end{array}$ & 0,04 \\
\hline \multicolumn{4}{|l|}{ Gráđa* } \\
\hline $1+2$ & $8(40)$ & $190(85)$ & \multirow{2}{*}{$<0,001$} \\
\hline $3+4$ & $12(60)$ & $34(15)$ & \\
\hline \multicolumn{4}{|l|}{ T-stig** } \\
\hline T1a & $11(46)$ & $204(88)$ & \multirow{2}{*}{$<0,001$} \\
\hline T3-4 & $13(54)$ & $27(12)$ & \\
\hline \multicolumn{4}{|l|}{ Vefjagerð $ð^{\star \star \star}$} \\
\hline Tærfrumugerð & $19(86)$ & $200(88)$ & \multirow{3}{*}{0,07} \\
\hline Totufrumugerð & 2 (9) & $22(10)$ & \\
\hline Litfælugerð & $1(5)$ & $5(2)$ & \\
\hline \multicolumn{4}{|l|}{ Aðgerð } \\
\hline Fullt brottnám & $9(36)$ & $198(85)$ & \multirow{3}{*}{$<0,001$} \\
\hline Hlutabrottnám & 0 & $25(11)$ & \\
\hline Engin aðgerð & $16(64)$ & $9(4)$ & \\
\hline
\end{tabular}

*Upplýsingar um gráđu vantaði hjá 13 sjúklingum. **Upplýsingar um T-stig vantaði hjá tveimur sjúklingum. ${ }^{* \star *} H$ já 8 sjúklingum vantað̋i vefjagreiningu.

\section{Umræða}

Sjúklingar með lítil NFK höfðu fjarmeinvörp í 10\% tilfella við greiningu. Peir sem höfðu meinvörp reyndust eldri en höfðu auk pess oftar einkenni sem rekja mátti til NFK, lægri blóðrauða og æxli af hærra T-stigi og æxlisgráðu.

Hlutfall sjúklinga með meinvörp reyndist hærra en í flestum sambærilegum rannsóknum, par sem pað er oftast á bilinu 2-6\%. ${ }^{8,15,16}$ Skýringin á pessu háa hlutfalli í okkar rannsókn er ekki augljós en íslenskar rannsóknir hafa sýnt svipaða lífhegðun sjúkdómsins og í nágrannalöndum okkar. ${ }^{1}$ Sennileg skýring er að flestar erlendu rannsóknanna tóku ekki með sjúklinga sem ekki gengust undir nýrnaskurðaðgerð. ${ }^{11,13}$ Tíðni meinvarpa gæti pví hafa verið vanmetin í eldri rannsóknum. Petta á pó ekki við um NSKCR-rannsóknina sem náði til 99\% NKF-tilfella sem greind voru í Svípjóð á árunum 2005-2008. Par greindust 7\% sjúklinga með æxli undir fjórum cm með meinvörp..$^{10}$ Í rannsókn okkar voru tekin með öll NFK og tilfelli fundin með leit í premur mismunandi skrám, meðal annars í Krabbameinsskrá og greiningarskrám sjúkrahúsa. Ekki er hægt að útiloka að einhver NFK hafi verið vanskráð í rannsókninni, líkt og í öðrum sambærilegum rannsóknum. Petta getur til dæmis átt við um lítil NFK í eldri einstaklingum sem ákveðið var að fylgjast með, án pess að pað hafi verið skráð sérstaklega í sjúkraskrá með greiningarnúmeri.

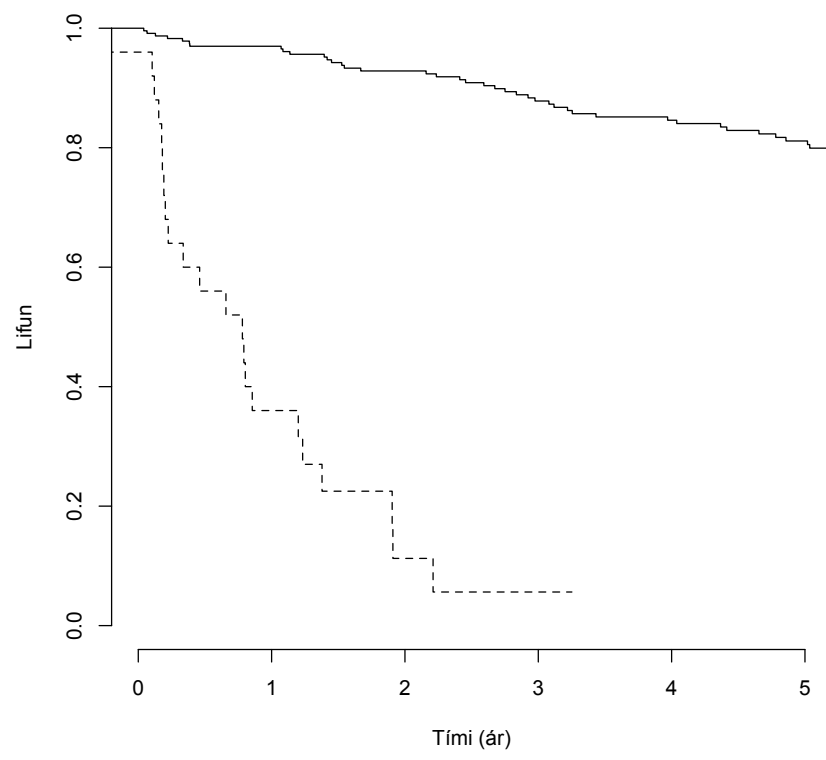

Mynd 2. Sjúkdómasértæk lifun sjúklinga með lítil nýrnafrumukrabbamein ( $\leq 4 \mathrm{~cm}$ ). Lifun sjúklinga með meinvörp er sýnd með brotinni línu en lifun sjúklinga án meinavarpa теð samfelldri línu.

Niðurstöður okkar hafa pýðingu við uppvinnslu og meðferð NFK-sjúklinga. Ljóst er að lítil NFK geta verið útbreidd við greiningu og pví rétt að taka slík tilfelli alvarlega. Petta endurspeglast í hárri tíðni meinvarpa en einnig peirri staðreynd að 5 ára sjúkdómasértæk lifun fyrir æxli undir 4 cm reyndist $94 \%$ en ekki $100 \%$. Pví er ljóst að sjúklingar með lítil NFK geta dáið úr sjúkdómnum, enda pótt peir séu ekki margir. Horfur lítilla NFK hafa almennt verið taldar góðar og hjá sjúklingum par sem skurðaðgerð er talin áhættusöm er jafnvel mælt með eftirliti í stað skurðaðgerðar ${ }^{7,8}$ eða annarri meðferð eins og hita- (radioablation) eða kuldameðferð (cryotherapy). ${ }^{8}$ Hér á landi hafa slíkir meðferðarkostir lítið verið notaðir, enda er skurðaðgerð best rannsakaða læknandi meðferðin og henni pví beitt í langflestum tilvikum. ${ }^{17}$

Áður voru nýrnafrumuæxli undir $2 \mathrm{~cm}$ að stærð flokkuð með góðkynja nýrnaæxlum, eins og nafnið „renal adenoma“ gefur til kynna. $^{18}$ Pessi skipting byggði meðal annars á krufningarannsókn frá 1950 en par kom í ljós að meinvörp reyndust afar fátíð fyrir minnstu æxlin sem voru pví flokkuð sem góðkynja. ${ }^{18}$ Árið 1997 voru lítil æxli aftur flokkuð með illkynja æxlum pegar ný vefjaflokkun, kennd við Heidelberg, var gefin út. ${ }^{19}$ Er pví litið á öll NFK með tærfrumuproskun eða af litfælugerð sem illkynja, óháð stærð, enda pótt totumyndandi æxli undir 2,0 cm séu afar sjaldan illkynja. ${ }^{14}$ Prátt fyrir að í pessari rannsókn hafi ekkert æxli undir 1 cm meinverpst (minnsta æxlið var 1,8 cm og hafði meinverpst til lungna og lifrar), styðja niðurstöður okkar að flokka beri minnstu æxlin með NFK.

Hlutfall lítilla NFK jókst stöðugt á rannsóknartímabilinu, eða úr tæpum $9 \%$ á áttunda áratug síðustu aldar í priðjung tilfella á síðasta áratugnum. Á sama tíma jókst hlutfall tilviljanagreindra æxla úr 14\% í 39\%. Í nýlegri íslenskri rannsókn sást að skýringin á pessari aukningu er fyrst og fremst aukin notkun tölvusneiðmynda og ómrannsókna við uppvinnslu annarra sjúkdóma í kviðarholi, til dæmis pegar leitað er að gall- eða nýrnasteinum. ${ }^{20}$ Sjúklingar með meinvörp reyndust eldri en peir sem höfðu staðbundinn sjúkdóm og munaði næstum tveimur árum. Niðurstöður 
okkar eru í samræmi við erlendar rannsóknir, par sem meðalaldur er oftast í kringum sextugt og hærri hjá sjúklingum með meinvörp. ${ }^{8,15}$ Hlutfall karla og kvenna var hins vegar svipað, sem kom á óvart, enda hlutfall karla og kvenna með NFK oftast í kringum prír á móti tveimur. ${ }^{21}$ Konur greinast pví hlutfallslega oftar með lítil æxli miðað við karla. Hugsanleg skýring gæti verið að konur gangist oftar undir myndrannsóknir á kviðarholi, sérstaklega tengt gallsteinasjúkdómum eins og sýnt var fram á í norskri rannsókn.22

Sjúklingar með meinvörp höfðu oftar almenn einkenni eins og megrun og slappleika en einnig ópægindi sem rekja mátti beint til meinvarpa, eins og beinverki. Petta er í samræmi við aðrar rannsóknir en sjúklingar með meinvörp hafa oftar langvarandi einkenni fyrir greiningu, samanborið við sjúklinga með staðbundin einkenni NFK, eins og kviðverki og blóðmigu. ${ }^{23}$

Marktækur munur reyndist á stærð æxla í hópunum en munurinn var pó aðeins 0,2 cm. Stærð NFK er á meðal sterkustu forspárpátta lífshorfa, enda einn helsti pátturinn í TNM-stigunarkerfinu. ${ }^{24}$ Í sumum erlendum rannsóknum, par á meðal sænsku NSKCR-rannsókninni, sáust tengsl milli stærðar æxlis og tíðni meinvarpa fyrir æxli á bilinu $0-4 \mathrm{~cm} \cdot{ }^{10,25}$ Í rannsókn okkar sást slíkt samband ekki og er pað í samræmi við rannsókn Thompson og félaga. ${ }^{12}$ Fyrir stærri æxli, sérstaklega pau sem eru yfir $7 \mathrm{~cm}$, virðast tengslin við tíðni meinvarpa pó sterk og styrkjast með vaxandi æxlisstærð. ${ }^{9,10,13}$

Eins og búast mátti við voru æxli sjúklinga með meinvörp á hærra T-stigi en hjá sjúklingum með staðbundinn sjúkdóm. Í flestum tilvikum var um æxli á stigi T3a að ræða, pað er æxlisvöxt út fyrir nýrað, en bláæðadrjólar (stig T3b) sáust sjaldan og T2 æxli voru undanskilin vegna stærðar. T-stigun er á meðal mikilvægustu forspárpátta lífshorfa en æðainnvöxtur í smáæðar (microinvasion) hefur í öðrum rannsóknum reynst sterkur áhættupáttur fyrir myndun meinvarpa hjá sjúklingum með lítil NFK. ${ }^{15}$ Í rannsókn okkar var ekki var litið sérstaklega á smáæðainnvöxt en hins vegar var æxlisgráđun hjá sjúklingum með meinvörp marktækt hærri en í viðmiðunarhópi. Vefjagerð var ekki marktækt frábrugðin í hópunum tveimur og tærfrumugerð (clear cell) langalgengasta vefjagerðin í peim báðum. Í erlendum rannsóknum er hlutfall tærfrumugerðar hjá NFK undir $4 \mathrm{~cm}$ á bilinu 70 til $80 \%$ en hlutfall totufrumugerðar (papillary) heldur hærra, eða 15\% 1́ stað $10 \%$ í pessari rannsókn. ${ }^{8,10}$

Styrkur pessarar rannsóknar er að hún nær til heillar pjóðar á 40 ára tímabili, en litið var á öll NFK en ekki aðeins sjúklinga sem gengust undir nýrnaskurðaðgerð. Auk pess voru öll vefjasýni yfirfarin af tveimur meinafræðingum. Rannsóknin var afturskyggn, sem er veikleiki pegar meta á einkenni sjúklinga og fylgikvilla.

Alls reyndust $10 \%$ sjúklinga með lítil NFK hafa meinvörp við greiningu, sem er hærra hlutfall en lýst hefur verið erlendis. Pessir sjúklingar eru eldri, með lægri blóðrauða og hafa æxli af hærra T-stigi og gráðu en peir sem ekki greinast með meinvörp. Niðurstöðurnar benda til pess að taka beri lítil NFK alvarlega og útiloka verði meinvörp líkt og gert er við stór NFK.

\section{Pakkir}

Pakkir fær Gunnhildur Jóhannesdóttir skrifstofustjóri fyrir hjálp við að afla klínískra upplýsinga. Rannsóknin var styrkt af Vísindasjóði Landspítala og Minningarsjóði Bergpóru Magnúsdóttur og Jakobs B. Bjarnasonar.

\section{Heimildir}

1. Thoroddsen A, Einarsson GV, Gudbjartsson T. Nýrnafrumukrabbamein á Íslandi. Læknablaðið 2007; 93: 283-97.

2. Gudbjartsson T, Thoroddsen A, Petursdottir V, Hardarson S, Magnusson J, Einarsson GV. Effect of incidental detection for survival of patients with renal cell carcinoma: results of population-based study of 701 patients. Urology 2005; 66: 1186-91.

3. Campbell SC, Novick AC, Belldegrun A, Blute ML, Chow GK, Derweesh IH, et al. Guideline for management of the clinical T1 renal mass. J Urol 2009; 182: 1271-9.

4. Ljungberg B, Cowan NC, Hanbury DC, Hora M, Kuczyk MA, Merseburger AS, et al. EAU guidelines on renal cell carcinoma: the 2010 update. Eur Urol 2010; 58: 398-406.

5. Go AS, Chertow GM, Fan D, McCulloch CE, Hsu CY. Chronic kidney disease and the risks of death, cardiovascular events, and hospitalization. N Engl J Med 2004; 351: 1296-305

6. Hollingsworth JM, Miller DC, Daignault S, Hollenbeck BK. Rising incidence of small renal masses: a need to reassess treatment effect. J Natl Cancer Inst 2006; 98: 1331-4.

7. Chow WH, Devesa SS, Warren JL, Fraumeni JF, Jr. Rising incidence of renal cell cancer in the United States. JAMA 1999; 281: 1628-31.

8. Pahernik S, Ziegler S, Roos F, Melchior SW, Thüroff JW. Small renal tumors: correlation of clinical and pathological features with tumor size. J Urol 2007; 178: 414-7.

9. Umbreit EC, Shimko MS, Childs MA, Lohse CM, Cheville JC, Leibovich BC, et al. Metastatic potential of a renal mass according to original tumour size at presentation. BJU Int 2012: 109: 190-4.
10. Gudmundsson E, Hellborg H, Lundstam S, Erikson S, Ljungberg B, Swedish Kidney Cancer Quality Register Group. Metastatic potential in renal cell carcinomas $\leq=7$ $\mathrm{cm}$ : Swedish Kidney Cancer Quality Register data. Eur cm: Swedish Kidney

11. Lughezzani G, Jeldres $C$, Isbarn $H$, Perrotte $P$, Shariat $S F$, Sun M, et al. Tumor size is a determinant of the rate of stage T1 renal cell cancer synchronous metastasis. J Urol 2009; 182: 1287-93

12. Klatte T, Patard JJ, de Martino M, Bensalah K, Verhoest G, de la Taille A, et al. Tumor size does not predict risk of metastatic disease or prognosis of small renal cell carcinomas. J Urol 2008; 179: 1719-26.

13. Thompson RH, Hill JR, Babayev Y, Cronin A, Kaag $\mathrm{M}$, Kundu S, et al. Metastatic renal cell carcinoma risk according to tumor size. J Urol 2009; 182: 41-5.

14. Eble JN, Sauter G, Epstein JI, Sesterhann IA, eds. World Health Organization International Classification of Tumours. Tumours of the urinary system and male genitial organs. IARC Press, Lyon 2004.

15. Kume $\mathrm{H}$, Suzuki M, Fujimura $T$, Fukuhara $\mathrm{H}$, Enomoto $\mathrm{Y}$, Nishimatsu $\mathrm{H}$, et al. Distant metastasis of renal cel carcinoma with a diameter of $3 \mathrm{~cm}$ or less-which is aggressive cancer? J Urol 2010; 184: 64-8.

16. Remzi M, Ozsoy M, Klingler HC, Susani M, Waldert M, Seitz C, et al. Are small renal tumors harmless? Analysis of histopathological features according to tumors $4 \mathrm{~cm}$ or less in diameter. J Urol 2006; 176: 896-9.

17. Cambio AJ, Evans CP. Management approaches to small renal tumours. BJU Int 2006; 97: 456-60.

18. Bell E. Renal Diseases 2nd. ed. Lea and Febiger, Fíladelfíu 1950.
19. Kovacs G, Akhtar M, Beckwith BJ, Bugert P, Cooper CS, Delahunt $\mathrm{B}$, et al. The Heidelberg classification of renal cell tumours. J Pathol 1997; 183: 131-3.

20. Palsdottir HB, Hardarson S, Petursdottir V, Jonsson A, Jonsson E, Sigurdsson MI, et al. Incidental detection of renal cell carcinoma is an independent prognostic marker: results of a long-term, whole population study. J Urol 2012; 187: 48-53.

21. Jónsson JG, Tryggvadóttir L. Krabbamein á Íslandi: upplýsingar úr Krabbameinsskrá fyrir tímabilið 1957-2006. Krabbameinsfélagið, Reykjavík 2008.

22. Beisland C, Medby PC, Beisland HO. Renal cell carcinoma: gender difference in incidental detection and cancerspecific survival. Scand J Urol Nephrol 2002; 36: 414-8.

23. Gudbjartsson T, Einarsson GV, Magnússon J. A population-based analysis of survival and incidental diagnosing of renal cell carcinoma patients in Iceland, 1971-1990. Scand J Urol Nephrol 1996; 30: 451-5.

24. Guinan P, Sobin LH, Algaba F, Badellino F, Kameyama S, MacLennan G, et al. TNM staging of renal cell carcinoma: Workgroup No. 3. Union International Contre le Cancer (UICC) and the American Joint Committee on Cancer (AJCC). Cancer 1997; 80: 992-3.

25. Kunkle DA, Crispen PL, Li T, Uzzo RG. Tumor size predicts synchronous metastatic renal cell carcinoma: implications for surveillance of small renal masses. J Urol 2007; 177: 1692-6; discussion 1697 


\section{ENGLISH SUMMARY}

\section{Small renal cell carcinomas and synchronous metastases}

Gudjonsson PS ${ }^{1}$, Mariusdottir $\mathrm{E}^{3}$, Palsdottir $\mathrm{HB}^{3}$, Jonsson $\mathrm{E}^{2}$, Petursdottir $\mathrm{V}^{3}$, Hardarson $\mathrm{S}^{3}$, Sigurdsson $\mathrm{Ml}^{2}$, Gudbjartsson $\mathrm{T}^{1,2}$

Objective: The incidence of renal cell carcinoma (RCC) is rising in part due to small tumors $(\leq 4 \mathrm{~cm})$ detected incidentally with abdominal imaging. Survival for small RCCs has been regarded as favorable and guidelines recommend partial rather than total nephrecteomy. We studied the frequency of synchronous metastasis in patients with small RCCs in Iceland.

Materials and methods: A retrospective study on 257 patients with RCC $\leq 4 \mathrm{~cm}$ out of 1102 RCC patients diagnosed in Iceland 1971-2010. Patients with metastasis were compared to those with localized disease. Hospital charts were reviewed and histology, TNM-stage and diseasespecific survival compared between groups.

Results: The proportion of small tumors increased from $9 \%$ in 19711980 to $33 \%$ in 2001-2010 ( $<<0,001)$ and incidental detection increased from $14 \%$ to $39 \%$ during the same period. Out of the 257 patients with small RCCs, 25 (10\%) had synchronous metastases, most frequently in lungs or bones. Patients with metastases were on average 1.9 years older, their tumors were $0.2 \mathrm{~cm}$ larger and more often located in the right kidney, their hemoglobin was lower and nuclear grade and T-stage higher. Histology was similar in both groups. Five-year survival of patients with and without metastases was 7 vs. $94 \%$, respectively $(p<0.001)$. Conclusions: One out of ten patients with small RCC has synchronous metastases at diagnosis. This is higher than in most previous reports that usually include surgical patients only. Patients with metastases are significantly older, more often symptomatic, their tumor are larger and their prognosis worse. Our results indicate that small RCC is a potentially systemic disease at diagnosis that has to be taken seriously.

Key words: Renal cell carcinoma, small tumors, metastases, stage, histology, survival.

Correspondence: Tómas Guðbjartsson, tomasgud@landspitali.is

${ }^{1}$ Faculty of Medicine, University of Iceland, Departments of ${ }^{2}$ Urology and ${ }^{2}$ Surgery, ${ }^{3}$ Department of Pathology, Landspitali University hospital. 